\title{
A Bibliometric Analysis of Blended Learning in Higher Education: Perception, Achievement and Engagement
}

\author{
Arumugam Raman \\ Universiti Utara Malaysia, Sintok, Kedah, Malaysia \\ http://orcid.org/0000-0001-5351-8944 \\ Raamani Thannimalai \\ Ministry of Education, Alor Setar, Kedah, Malaysia \\ https:// orcid.org/0000-0001-8758-4202 \\ Yahya Don \\ Universiti Utara Malaysia, Sintok, Kedah, Malaysia \\ https:/ / orcid.org/0000-0002-6340-4999 \\ Mohan Rathakrishnan \\ Universiti Utara Malaysia, Sintok, Kedah, Malaysia \\ https://orcid.org/0000-0002-3360-5343
}

\begin{abstract}
This article presents a bibliometric analysis of publications on blended learning in higher education. The analysis is grounded on statistics obtained from the online Scopus database on 11 December 2019. The study used Microsoft Excel to conduct a frequency analysis, VOSviewer for data visualization, and Harzing's Publish or Perish for citation metrics and analysis. In total 1,064 valid documents were analyzed, based on keyword search results for "blended learning", "perception", "achievement", "engagement", "higher education" and "bibliometric analysis". This article reports descriptive and content analysis on document type and source type. Analysis shows that number of publications per year increased from 2000 to 2018. English is the most widely used language for publications, and most publications are from the social sciences. The United States contributes the most publications. The most active journals, influential institutions, citation metrics and highly cited articles are listed. Network visualization maps demonstrate keyword analysis of author keywords; co-authorship by country and author; number of authors per document; citations by country and document; co-occurrence of all keywords; and, lastly, co-citation by cited sources. The visibility of work on blended learning in highly cited journals in the past two decades reveals that blended learning has gained significant attention among educators and researchers. Future research
\end{abstract}


could include systematic literature reviews or other mapping tools, such as HistCite.

Keywords: achievement; bibliometric analysis; blended learning; engagement; perception

\section{Introduction}

Blended learning (BL) is an educational approach first postulated in 2000 (Cooney et al., 2000); since then, it has been used in many fields of leadership training (Voci \& Young, 2001) and higher education (Garrison \& Kanuka, 2004; Raman \& Rathakrishnan, 2019). However, not many bibliometric analyses have been carried out on BL in higher education contexts, especially not related to perception, achievement, and engagement (Dwivedi et al., 2019). Bibliometrics is a quantitative analytic technique that uses mathematical and statistical methods to ascertain the relationships between and impacts of publications in a particular field of study (Lee et al., 2020). In bibliometrics, bibliometric mapping is an important research area that is fast gaining popularity among e-learning researchers (Börner et al., 2003). However, there is still a dearth of bibliometric information relating to BL and e-learning research globally in the educational setting (Diem \& Wolter, 2013; Lee et al., 2009) and information technology (Hsiao et al., 2015). Moreover, the latest publications on e-learning demonstrate a wide bibliometric interrelation amongst its articles, which are predominantly in the social sciences (Tibaná-Herrera et al., 2018).

Engagement is a widely relevant predictor of student satisfaction and achievement in $\mathrm{BL}$, because engagement has the potential to improve the student experience (Lane et al., 2021). Moreover, there is a significant correlation between BL and students' perception of using BL approaches, and academic achievement (Alamri, 2021). However, there is limited visibility of BL in higher education in relation to students' perceptions about $\mathrm{BL}$, and its role in achievement and engagement. Therefore, this research aimed to fill this gap, by investigating the scholarly networks and worldwide trends involving BL in higher education, based on a bibliometric analysis of highly cited articles published between 2000 to 2019 and visible in the Scopus database. The purpose of this research was to evaluate published literature on $\mathrm{BL}$, perception, achievement, engagement in higher education, based on publication output, author keyword occurrence, most productive journals, most productive institutions, authors, and country contributions.

The purpose of this paper is to examine the effect of BL on perception, achievement, and engagement in higher education. The central research questions relating to BL in higher education that guided the bibliometric analysis of this study are as follows: RQ1: What are the document and source types? RQ2: What is the research productivity? RQ3: What are the most used languages in documents? RQ4: What subject areas are researching BL in higher education? RQ5: What are the most active journals publishing papers? RQ6: What are the most influential institutions that contributed to BL in higher education? RQ7: What is the distribution of author keywords and co-occurrences of author 
keywords? RQ8: What is the geographical distribution of publications by country? RQ9: How many authors collaborate per document? RQ10: Who are the most active authors? RQ11: What is the distribution of co-authorship by authors? RQ12: What is the citation analysis of documents?

\section{Literature Review}

\subsection{Bibliometric Mapping}

Bibliometrics can be defined as quantitative and descriptive statistical analysis of publications, such as journal articles (Ding et al., 2016), conference proceedings papers (Michels \& Fu, 2014), and book chapters (Zuccala \& van Leeuwen, 2011). By searching the Web of Science and Scopus databases by topic, author, journal, and time period, bibliographic data can be retrieved. Over the past two decades, quantitative analysis of publication and citation data has been widely used in education settings to assess prominent authors, conceptual and intellectual maps, and trends in scientific ecosystems (Aria \& Cuccurullo, 2017). The creation of bibliometric maps (distance-based maps) and the graphical illustration of those maps (graph-based maps) are two aspects of bibliometric mapping. Constructions of maps are more widely used and discussed in bibliometric literature than graphical illustrations of maps (Van Eck \& Waltman, 2010). Computer programs, such as SPSS and Pajek, generate simple graphical illustrations for bibliometric literature, which are only suitable for small maps of less than 100 items (Chen, 2003; Skupin, 2004). Therefore, a new computer program that can plot larger maps was developed (Klavans \& Boyack, 2006, Van Eck \& Waltman, 2020).

\subsection{Visualisation of Similarities (VOSviewer)}

VOS (Visualisation of Similarities) viewer is a computer program that was designed to create and visualise bibliometric maps, free of charge (Van Eck \& Waltman, 2020). Several computer programs can be used for bibliometric mappings, such as Histcite, SPSS and Pajek (Chen, 2003; Skupin, 2004), but VOS emphasizes graphical representation. The speciality of VOSviewer is that it can display large bibliometric maps, for example, it can construct maps of authors or journals based on keyword, co-citation, and co-occurrence data. Another advantage of VOS is that it can be used for more than 100 items. The VOS mapping technique demonstrates excellent performance in viewing and constructing maps, the procedures of which are wholly integrated into VOSviewer. Three types of visualizations can be demonstrated, namely network, overlay, and density visualization. However, for this study, only the network visualization was generated and analyzed (Van Eck \& Waltman, 2020).

\subsection{Scopus Database}

Sophisticated analytical tools are now available to ensure that bibliometric analysis is accurate, and to cover a large pool of publications over long periods. Some of the widely used databases are Scopus, Google Scholar, and Web of Science (Li et al., 2010). For this study, the Scopus database was searched using keywords applicable to this article. As of 2 February 2020, no results were returned by the Scopus database for the keywords "blended learning", "perception", "achievement", "engagement", "higher learning" and "bibliometric analysis". However, there was an article reporting a study on the relationship 
between student perceptions in BL courses and their in-course achievement in higher education (Owston et al., 2013). This analysis was carried out due to the existence of this prevailing gap between BL and perceptions, achievement, and engagement in higher education.

\subsection{Bibliometric Indicators}

Bibliometrics measures the impact of scientific research by using bibliometric indicators, such as the impact factor and the h-index. Bibliometric indicators measure the impact of a paper by counting the number of other papers that have cited it. Harzing's Publish or Perish software is widely used to calculate citation metrics, such as h-index and g-index (Harzing, 2020).

\subsection{Definitions of Blended Learning, Perception, Achievement and Engagement}

BL systems integrate face-to-face instruction with computer-mediated instruction (Graham, 2018). BL is described by Garrison and Kanuka (2004, p. 96) as "the careful combination of classroom face-to-face learning experiences with online learning experiences".

Perception can refer to the presence of an experiencing person or perceiver; second, it can be what is being perceived (object, person, situation, or relationship); third, the context of the situation in which objects, events, or persons are perceived; and finally, the process nature of perception, which begins with the experience of several stimuli by the perceiver (Jordaan \& Jordaan, 1996, cited by Lewis, 2001).

Achievement refers to success in relation to the academic objectives that students are required to accomplish as a result of their learning activities (Hattie \& Anderman, 2013). Engagement, according to the National Survey of Student Engagement, is defined as the amount of time students devote to educational activities in order to achieve the desired outcomes, as well as the quality of their related efforts (Kuh, 2009). Furthermore, engagement is described as "the degree to which students participate in activities that have been linked to high-quality learning outcomes in higher education research" (Krause \& Coates, 2008).

\section{Method}

The data in this analysis were established by searching 24,600 active titles and 5,000 publishers on the Scopus database and Scopus indexed content. Although several databases are widely available, the bibliometric analysis in this research is based entirely on Scopus databases. In addition, to create sample articles for the analysis, only five keywords were utilized as search terms, namely "blended learning"; "perception"; "achievement"; "engagement", and "higher education". Network visualization and bibliometric indicators will be illustrated to answer the research questions.

Scopus uses rigorous original metadata to associate people, published theories, and institutions. By using refined tools and analytics, Scopus creates accurate citation outcomes and comprehensive researcher profiles. "Blended learning" OR 
"perception" OR "achievement" OR "engagement" AND "higher education" was used as the string to search titles, abstracts, and keywords. Documents published between 2000 to 2019 were retrieved for analysis. This research employed the stepwise procedure commonly used in bibliometric studies, which is illustrated in the flowchart in Figure 1 (Zare et al., 2017).

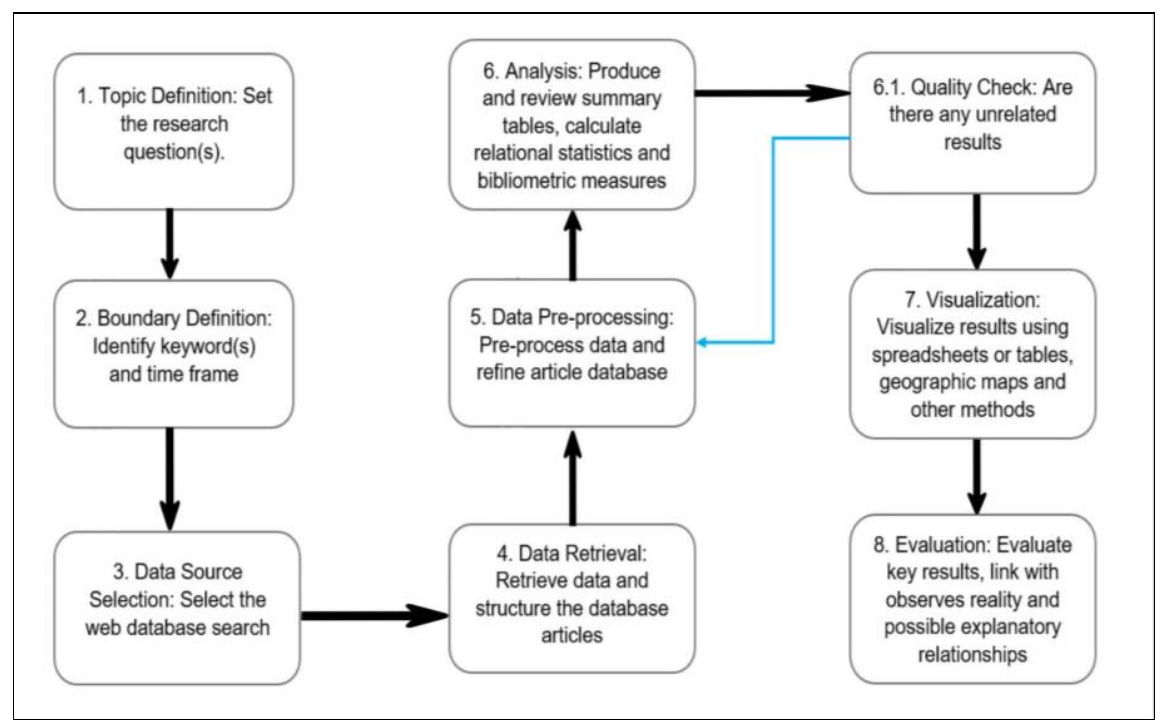

Figure 1: Steps in the bibliometric research method (Zare et al., 2017)

\subsection{Bibliometric analysis}

Bibliometrics is a computerized investigation of publications by statistical designs (Ellegaard \& Wallin, 2015). Over the last decade, bibliometric analysis has gained popularity as a method that can reveal the trends of visibility in open-access and conference publications. Publication outlet, type of publication, authorship, affiliation, country, and h-index are most frequently analyzed (Ahmi \& Mohamad, 2019). According to Rusly et al. (2019), a bibliometric analysis could analyse data concerning publications over a period, by referring to frequency of keywords, citations, and authors.

\subsection{Source and Data Collection}

The search query, "The Effect of Blended Learning on Perception, Achievement, and Engagement in Higher Education" was searched within the 'article title' box at the Scopus database on 2 February 2020. Overall, 1,064 documents were produced for advanced investigation. The retrieval data from Scopus database were exported in the form of RIS and CSV for further analysis. Software, such as Microsoft Excel, VOSviewer and Harzing's Publish and Perish, was used to analyze the collected Scopus documents. Microsoft Excel 2019 was used to calculate the frequency and percentage of each publication, as well as to generate suitable graphical representations; VOSviewer (version 1.6.15) was used to visualize the bibliometric networks; and citation metrics were calculated using Harzing's Publish and Perish program (Mansour et al., 2021). 


\section{Results}

The research findings comprise information on document and source types; research productivity; the language of documents; subject area; most active journals; author keywords analysis and co-occurrences of author keywords; geographical distribution of publications; the number of authors per document; most active authors, co-authorship by authors, most influential institutions; and citation analysis. In addition, visualization maps were used to enhance keyword analysis, the explanation of geographical distribution of publications, the number of authors per document, most influential institutions, highly cited articles/most influential papers through Google Scholar (2000-2019), the geographical distribution of publications, and frequently cited articles through Google Scholar (2000-2019).

\subsection{Document and source types}

Publications obtained from the Scopus database can be classified according to document type and source type. Document type includes information on the origin of publications, such as journal articles, conference papers, and book chapters (Sigogneau, 2000; Sweileh et al., 2017; Ahmi \& Mohamad, 2019). Conference papers are classified as papers that were presented at conferences, and which might also have been published as journal articles (Ahmi \& Mohamad, 2019). In this study, nine types of documents were published by Scopus between the years 2000 and 2019 (Table 1). Out of the 1,064 documents published, 723, or $67.95 \%$, were articles. This was followed by 145 conference papers (13.635\%); 112 book chapters (10.53\%); 38 reviews (3.57\%); 18 books (1.69\%); eight editorials $(0.75 \%)$; and seven notes $(0.66 \%)$. A total of six documents were classified as errata $(0.56 \%)$, and seven documents were undefined by Scopus $(0.66 \%)$.

Table 1. Document type

\begin{tabular}{|l|c|c|}
\hline Document type & Frequency & $\mathbf{\%} \mathbf{( N = 1 , 0 6 4 )}$ \\
\hline Article & 723 & 67.95 \\
\hline Conference Paper & 145 & 13.63 \\
\hline Book Chapter & 112 & 10.53 \\
\hline Review & 38 & 3.57 \\
\hline Book & 18 & 1.69 \\
\hline Editorial & 8 & 0.75 \\
\hline Note & 7 & 0.66 \\
\hline Erratum & 6 & 0.56 \\
\hline Undefined & 7 & 0.66 \\
\hline Total & $\mathbf{1 , 0 6 4}$ & $\mathbf{1 0 0 . 0 0}$ \\
\hline
\end{tabular}

Documents published under the category of source type consisted of journals $(73.21 \%)$ - the highest percentage - followed by books $(11.84 \%)$; conference proceedings $(11.65 \%)$; book series $(3.10 \%)$ and trade publications $(0.19 \%)$ (Table 2). Source type conference papers can be published as either book chapters or conference proceedings (Sweileh et al., 2017). 
Table 2. Source type

\begin{tabular}{|l|c|c|}
\hline \multicolumn{1}{|c|}{ Source type } & Frequency & \% (N=1,064) \\
\hline Journals & 779 & 73.21 \\
\hline Books & 126 & 11.84 \\
\hline Conference Proceedings & 124 & 11.65 \\
\hline Book Series & 33 & 3.10 \\
\hline Trade Publications & 2 & 0.19 \\
\hline Total & $\mathbf{1 , 0 6 4}$ & $\mathbf{1 0 0 . 0 0}$ \\
\hline
\end{tabular}

\subsection{Research productivity}

Research productivity is normally defined by the number of publications (Fox, 1983; Reynolds, 1971). Analysis of documents by year of publication enables researchers to track the pattern and visibility of research (Ahmi \& Mohamad, 2019). In this study, the total annual publications ascertained research productivity. It is illustrated by a percentage and cumulative percentage of publications from 2000 to 2019. This analysis found that the number of publications per year, the percentage, and cumulative percentage of publications increased gradually from 2000 to 2018, with a slight dip in 2016, as shown in Table 3 and Figure 2. The highest number was achieved in 2018, with 151 publications, and the lowest in 2000, with only five publications. This finding shows that the search strings of this study had increased in visibility in the last two decades and is increasingly becoming a favorite research topic, especially among e-learning researchers (Johnson et al., 2016).

Table 3: Publications by year

\begin{tabular}{|c|c|c|c|}
\hline Year & $\begin{array}{c}\text { No. of } \\
\text { publications }\end{array}$ & $\begin{array}{c}\text { Percentage }(\%) \\
(\mathrm{N}=1,064)\end{array}$ & $\begin{array}{c}\text { Cumulative } \\
\text { percentage }(\%)\end{array}$ \\
\hline 2000 & 5 & 0.47 & 0.47 \\
\hline 2001 & 6 & 0.56 & 1.03 \\
\hline 2002 & 6 & 0.56 & 1.59 \\
\hline 2003 & 5 & 0.47 & 2.06 \\
\hline 2004 & 13 & 1.22 & 3.28 \\
\hline 2005 & 15 & 1.41 & 4.69 \\
\hline 2006 & 12 & 1.13 & 5.82 \\
\hline 2007 & 16 & 1.50 & 7.32 \\
\hline 2008 & 28 & 2.63 & 9.95 \\
\hline 2009 & 29 & 2.73 & 12.68 \\
\hline 2010 & 48 & 4.51 & 17.19 \\
\hline 2011 & 44 & 4.14 & 21.33 \\
\hline 2012 & 61 & 5.73 & 27.06 \\
\hline 2013 & 74 & 6.95 & 34.01 \\
\hline 2014 & 83 & 7.80 & 41.81 \\
\hline 2015 & 109 & 10.24 & 52.05 \\
\hline 2016 & 94 & 8.83 & 60.88 \\
\hline 2017 & 117 & 11.02 & 71.9 \\
\hline 2018 & 151 & 14.19 & 86.09 \\
\hline 2019 & 148 & 13.91 & 100 \\
\hline Total & 1,064 & 100 & \\
\hline
\end{tabular}




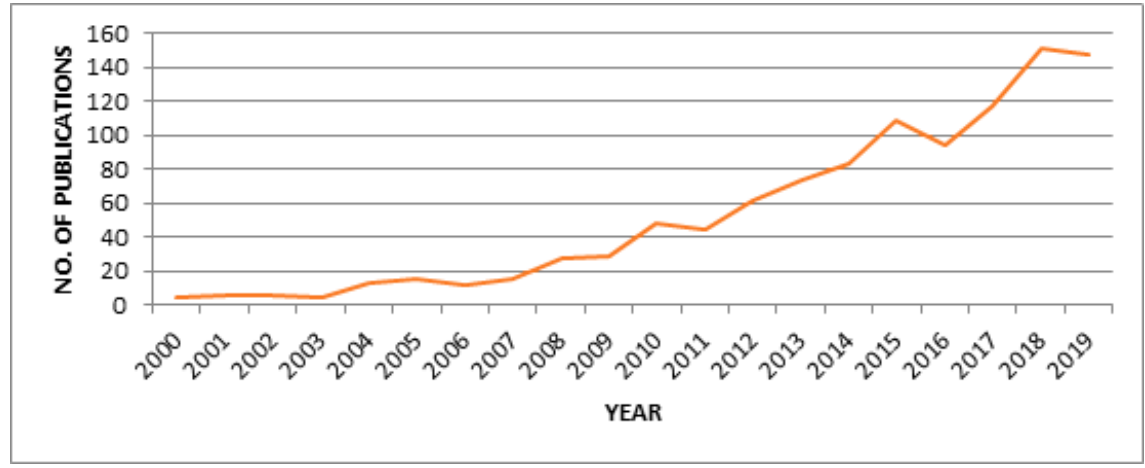

Figure 2. Number of publications by year

\subsection{Language of documents}

English is the most widely used language for publications, covering $92.89 \%$ of the total number of publications, followed by Spanish $(3.23 \%)$ and Portuguese $(1.94 \%)$ (Table 4). The rest of the publications were in other languages, namely Afrikaans, French, German and Croatian. Asian languages, such as Japanese, Korean, and Thai, were used in $0.09 \%$ of publications. A few other European languages that are used in publications in Scopus are Russian, Turkish, and Ukrainian (0.095). A total of 19 publications were found to be published in dual languages, which explains the frequency of 1,083 , although the total number of publications in this analysis is 1,064 (Table 1 ).

Table 4: Languages used for publications

\begin{tabular}{|l|c|c|}
\hline \multicolumn{1}{|c|}{ Language } & Frequency $^{*}$ & \% (N=1083) \\
\hline English & 1,006 & 92.89 \\
\hline Spanish & 35 & 3.23 \\
\hline Portuguese & 21 & 1.94 \\
\hline Afrikaans & 5 & 0.46 \\
\hline French & 4 & 0.37 \\
\hline Croatian & 3 & 0.28 \\
\hline German & 3 & 0.28 \\
\hline Japanese & 1 & 0.09 \\
\hline Korean & 1 & 0.09 \\
\hline Russian & 1 & 0.09 \\
\hline Thai & 1 & 0.09 \\
\hline Turkish & 1 & 0.09 \\
\hline Ukrainian & 1 & 0.09 \\
\hline Total & $\mathbf{1 , 0 8 3}$ & $\mathbf{1 0 0 . 0 0}$ \\
\hline
\end{tabular}

*19 documents were prepared in dual languages

\subsection{Subject area}

The publications were categorized further according to 25 subject areas, as summarized in Table 5. Results confirm that BL is a method that most widely used in the social sciences, as $53.93 \%$ of all publications in this study are, in fact, about the social sciences. Next-most-common subject areas are computer science $(12.46 \%)$ and business, management and accounting (8.12\%). BL and perception of, and achievement and engagement in higher education are also integrated into other subject areas, as shown in Table 5. Other significant contributing areas are 
the arts and humanities, psychology, and engineering. The total frequency of 1,565 , which is much higher than the actual total of 1,064 publications, indicates that $\mathrm{BL}$ is a multidisciplinary field about which work is published and categorized across more than one subject area.

Table 5. Subject area

\begin{tabular}{|l|c|c|}
\hline \multicolumn{1}{|c|}{ Subject area } & Frequency & \% (N=1,565) \\
\hline Social Sciences & 844 & 53.93 \\
\hline Computer Science & 195 & 12.46 \\
\hline Business, Management and Accounting & 127 & 8.12 \\
\hline Arts and Humanities & 77 & 4.92 \\
\hline Psychology & 69 & 4.41 \\
\hline Engineering & 65 & 4.15 \\
\hline Economics, Econometrics and Finance & 35 & 2.24 \\
\hline Medicine & 25 & 1.60 \\
\hline Decision Sciences & 21 & 1.34 \\
\hline Mathematics & 20 & 1.28 \\
\hline Environmental Science & 19 & 1.21 \\
\hline Health Professions & 15 & 0.96 \\
\hline Energy & 9 & 0.58 \\
\hline Agricultural and Biological Sciences & 8 & 0.51 \\
\hline Multidisciplinary & 8 & 0.51 \\
\hline Physics and Astronomy & 6 & 0.38 \\
\hline Biochemistry, Genetics and Molecular Biology & 5 & 0.32 \\
\hline Earth and Planetary Sciences & 5 & 0.32 \\
\hline Nursing & 4 & 0.26 \\
\hline Chemical Engineering & 2 & 0.13 \\
\hline Neuroscience & 2 & 0.13 \\
\hline Pharmacology, Toxicology and Pharmaceutics & 2 & 0.13 \\
\hline Materials Science & 1 & 0.06 \\
\hline Veterinary & 1 & 0.06 \\
\hline Total & $\mathbf{1 , 5 6 5}$ & $\mathbf{1 0 0}$ \\
\hline *Publications were classified according to source title. Some of the source \\
titles were categorized in more than one subject area. & \\
\hline
\end{tabular}

\subsection{Most active journals}

The search for the most active journals generated 15 journals, as listed in Table 6 . Studies in Higher Education topped the list, with 20 articles. This was followed by Higher Education Research and Development (16), Higher Education (14), Journal of Applied Research in Higher Education (12 articles), and Journal of Further and Higher Education (11 articles). Ten articles on BL and the keywords analyzed in this paper were published in Assessment and Evaluation in Higher Education and Computers and Education Journal. The journals that published seven articles over the period studied are British Journal of Educational Technology, Christian Higher Education, Higher Education Policy and Proceedings of The European Conference on E-Learning (Ecel).

Cite score, which encompasses more social sciences and humanities journals, is grounded on information obtained from the Scopus database, and has a threeyear citation window. The top three ranked journals Internet and Higher Education 
(9.41), followed by Computers in Education (7.72) and British Journal of Educational Technology (4.07). Although Higher Education (N/A) published 14 articles in that period, Scopus did not provide the cite score.

Table 6. Most active journals

\begin{tabular}{|l|c|c|}
\hline Journals & $\begin{array}{c}\text { Number } \\
\text { of } \\
\text { Articles }\end{array}$ & $\begin{array}{c}\text { Cite Score } \\
\mathbf{( 2 0 1 8 )}\end{array}$ \\
\hline Studies in Higher Education & 20 & 3.28 \\
\hline Higher Education Research and Development & 16 & 2.58 \\
\hline Higher Education & 14 & N/A \\
\hline Journal of Applied Research in Higher Education & 12 & 0.64 \\
\hline Journal of Further and Higher Education & 11 & 1.63 \\
\hline Assessment and Evaluation in Higher Education & 10 & 2.72 \\
\hline Computers and Education & 10 & 7.72 \\
\hline Internet and Higher Education & 9 & 9.41 \\
\hline Journal of Higher Education Policy and Management & 9 & 1.55 \\
\hline Communications in Computer and Information Science & 8 & 0.46 \\
\hline Quality Assurance in Education & 8 & 1.53 \\
\hline British Journal of Educational Technology & 7 & 4.07 \\
\hline Higher Education Policy & 7 & 1.47 \\
\hline Total & $\mathbf{1 4 1}$ & \\
\hline
\end{tabular}

\subsection{Most influential institutions}

The most influential institutions that contributed documents on BL were also analyzed for this paper. Out of 164 institutions that had published a minimum of seven publications, Monash University (Australia) topped the list, with 11 publications (6.67\%). This was followed by Universiti Teknologi Malaysia, Curtin University (Australia), and the University of London, with ten publications $(6.06 \%)$ each. This proves that BL and e-learning have gained the attention of researchers from both Western and Eastern countries. It is interesting that eight of the top 20 institutions were in Australia, four in the United Kingdom; three in Portugal; two each in Malaysia and the United States of America, and one in Spain.

Table 7. Most influential institutions

\begin{tabular}{|l|c|c|}
\hline \multicolumn{1}{|c|}{ Country } & Frequency & \% (N=165) \\
\hline Monash University & 11 & 6.67 \\
\hline Universiti Teknologi Malaysia & 10 & 6.06 \\
\hline Curtin University & 10 & 6.06 \\
\hline University of London & 10 & 6.06 \\
\hline RMIT University & 9 & 5.45 \\
\hline Universidade do Minho & 9 & 5.45 \\
\hline Universidade de Aveiro & 9 & 5.45 \\
\hline The University of Sydney & 9 & 5.45 \\
\hline Universidade de Lisboa & 9 & 5.45 \\
\hline National University of Ireland Galway & 8 & 4.85 \\
\hline Griffith University & 8 & 4.85 \\
\hline Universitat de Barcelona & 7 & 4.24 \\
\hline
\end{tabular}




\begin{tabular}{|l|c|c|} 
Universiti Teknologi MARA & 7 & 4.24 \\
\hline Brigham Young University & 7 & 4.24 \\
\hline University of Salford & 7 & 4.24 \\
\hline University of Southern Queensland & 7 & 4.24 \\
\hline Indiana University & 7 & 4.24 \\
\hline Lancaster University & 7 & 4.24 \\
\hline University of Plymouth & 7 & 4.24 \\
\hline University of Queensland & 7 & 4.24 \\
\hline Total & $\mathbf{1 6 5}$ & $\mathbf{1 0 0 . 0 0}$ \\
\hline
\end{tabular}

\subsection{Analysis of author keywords and co-occurrences of author keywords}

Descriptive analysis of the 20_keywords most frequently used by authors revealed that the most frequently used keyword is "higher education" (15.24\%), followed by "students" (5.85\%), "education" (4.08\%), "blended learning" (3.50\%), and "elearning" (3.16\%). "Perception" and "student engagement" were found to each represent only $2.19 \%$ of the total search returns of this study, followed by "academic achievement", which had a percentage of $1.00 \%$ (Table 8 ).

Table 8: Author keywords analysis

\begin{tabular}{|l|c|c|}
\hline \multicolumn{1}{|c|}{ Author keywords } & Frequency & Percentage \\
\hline Higher Education & 396 & $15.24 \%$ \\
\hline Students & 152 & $5.85 \%$ \\
\hline Education & 106 & $4.08 \%$ \\
\hline Blended Learning & 91 & $3.50 \%$ \\
\hline E-learning & 82 & $3.16 \%$ \\
\hline Teaching & 78 & $3.00 \%$ \\
\hline Perception & 57 & $2.19 \%$ \\
\hline Student Engagement & 57 & $2.19 \%$ \\
\hline Human & 39 & $1.50 \%$ \\
\hline Engineering Education & 36 & $1.39 \%$ \\
\hline Student & 35 & $1.35 \%$ \\
\hline Higher Education Institutions & 33 & $1.27 \%$ \\
\hline Education Computing & 30 & $1.15 \%$ \\
\hline Engagement & 29 & $1.12 \%$ \\
\hline Computer-aided Instruction & 28 & $1.08 \%$ \\
\hline Article & 27 & $1.04 \%$ \\
\hline Learning & 27 & $1.04 \%$ \\
\hline University & 27 & $1.04 \%$ \\
\hline Academic Achievement & 26 & $1.00 \%$ \\
\hline Humans & 25 & $0.96 \%$ \\
\hline
\end{tabular}

To map widely used keywords with VOSviewer, co-occurrence analysis was administered and author keywords were chosen. The network visualization map of co-occurrences by author keywords was generated and is shown in Figure 3. From the analysis, six clusters of blended learning were developed. The largest label and circle, which is for "higher education", reveals that the keyword "higher education" has the largest number of occurrences in the Scopus database. The second cluster, which has the second-largest font, represents "blended learning". The third cluster represents "student engagement" and is linked to other 
keywords, such as "social media", "Web 2.0", and "Facebook". This is followed by "employability", which is linked to "mobile learning", "instructional design", "motivation", "academic achievement", and, lastly ", perception".

The distance between "higher education" and "assessment" was, furthermore, compared to the distance between "higher education" and "student engagement". This means that the relationship between "higher education" and "student engagement" is stronger than that between "higher education" and "assessment". The distance between "higher education" and "blended learning" is the shortest, and this shows that the relationship between these two variables is the strongest. The relationship between "higher education" and "achievement" is the weakest, as these two terms are situated furthest away from each other.

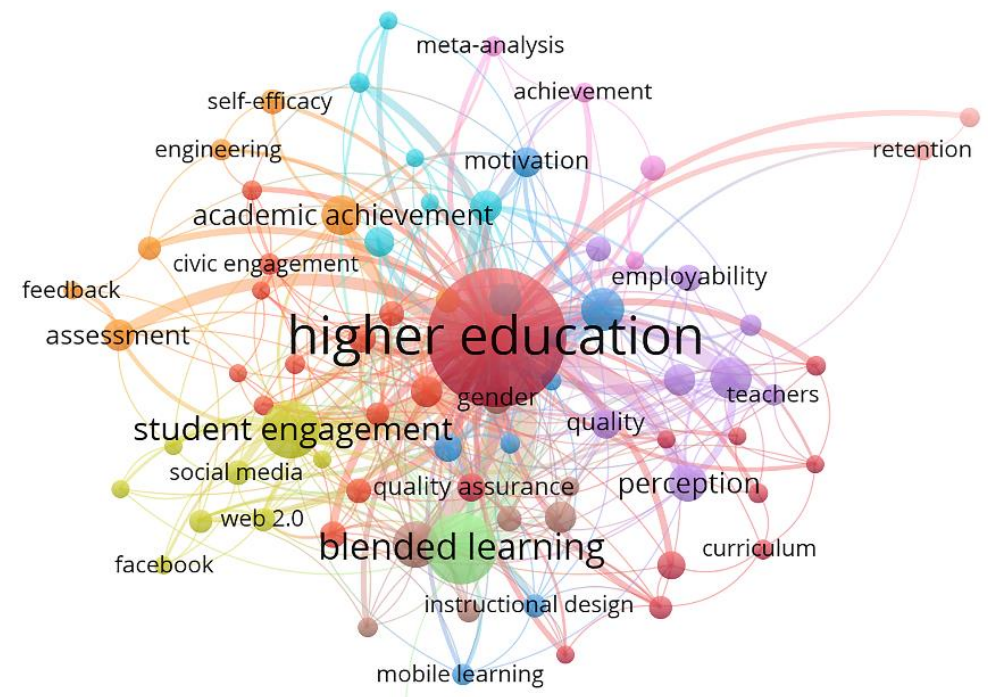

VOSviewer

teaching/learning strategies

Minimum number of occurrences of a keyword: 5

Number of keywords to be selected: 5

Figure 3. Network visualization map of co-occurrences by author keyword

\subsection{Geographical distribution of publications}

A total of 1,220 publications from around the world were identified in the Scopus database for the period of study. However, after descriptive analysis, we selected only the 20 most influential countries. From 2000 to 2019, a total of 938 papers was published. Overall, the United States contributed the largest number of publications on BL and the keywords researched (22.71\%), followed by the United Kingdom (19.83\%), Australia (11.19\%), and Spain (7.25\%). This study reveals that developed countries were at the forefront of research on BL and other fields of educational technology. Following closely behind the leading countries were developing countries, such as Malaysia (5.65\%), South Africa (3.52\%), and Brazil (2.675). 
Table 9. Top 20 countries' contribution to publications

\begin{tabular}{|l|c|c|}
\hline Country & Frequency & $\mathbf{\%} \mathbf{~ ( N = 9 3 8 ) ~}$ \\
\hline United States & 213 & 22.71 \\
\hline United Kingdom & 186 & 19.83 \\
\hline Australia & 105 & 11.19 \\
\hline Spain & 68 & 7.25 \\
\hline Malaysia & 53 & 5.65 \\
\hline Portugal & 35 & 3.73 \\
\hline South Africa & 33 & 3.52 \\
\hline Brazil & 25 & 2.67 \\
\hline Canada & 25 & 2.67 \\
\hline Ireland & 22 & 2.35 \\
\hline Turkey & 22 & 2.35 \\
\hline Belgium & 20 & 2.13 \\
\hline Germany & 20 & 2.13 \\
\hline India & 19 & 2.03 \\
\hline Netherlands & 19 & 2.03 \\
\hline Indonesia & 17 & 1.81 \\
\hline Chile & 15 & 1.60 \\
\hline New Zealand & 15 & 1.60 \\
\hline Hong Kong & 14 & 1.49 \\
\hline China & 12 & 1.28 \\
\hline Total & $\mathbf{9 3 8}$ & $\mathbf{1 0 0 . 0 0}$ \\
\hline
\end{tabular}

The network visualization map of the co-authorship by country is shown in Figure 4. This analysis was carried out using fractional counting, with a minimum of three documents and citations per country. The United States contributed the most publications on BL, followed by the United Kingdom, Australia, Spain and Malaysia. The links between differently colored clusters show that authors from different countries collaborated to produce articles, for example, between the United States, United Kingdom, and Australia. There was also collaboration among authors from countries within the same cluster, for example, authors from Australia, Turkey, Hong Kong, New Zealand, and Belgium produced papers collectively. 


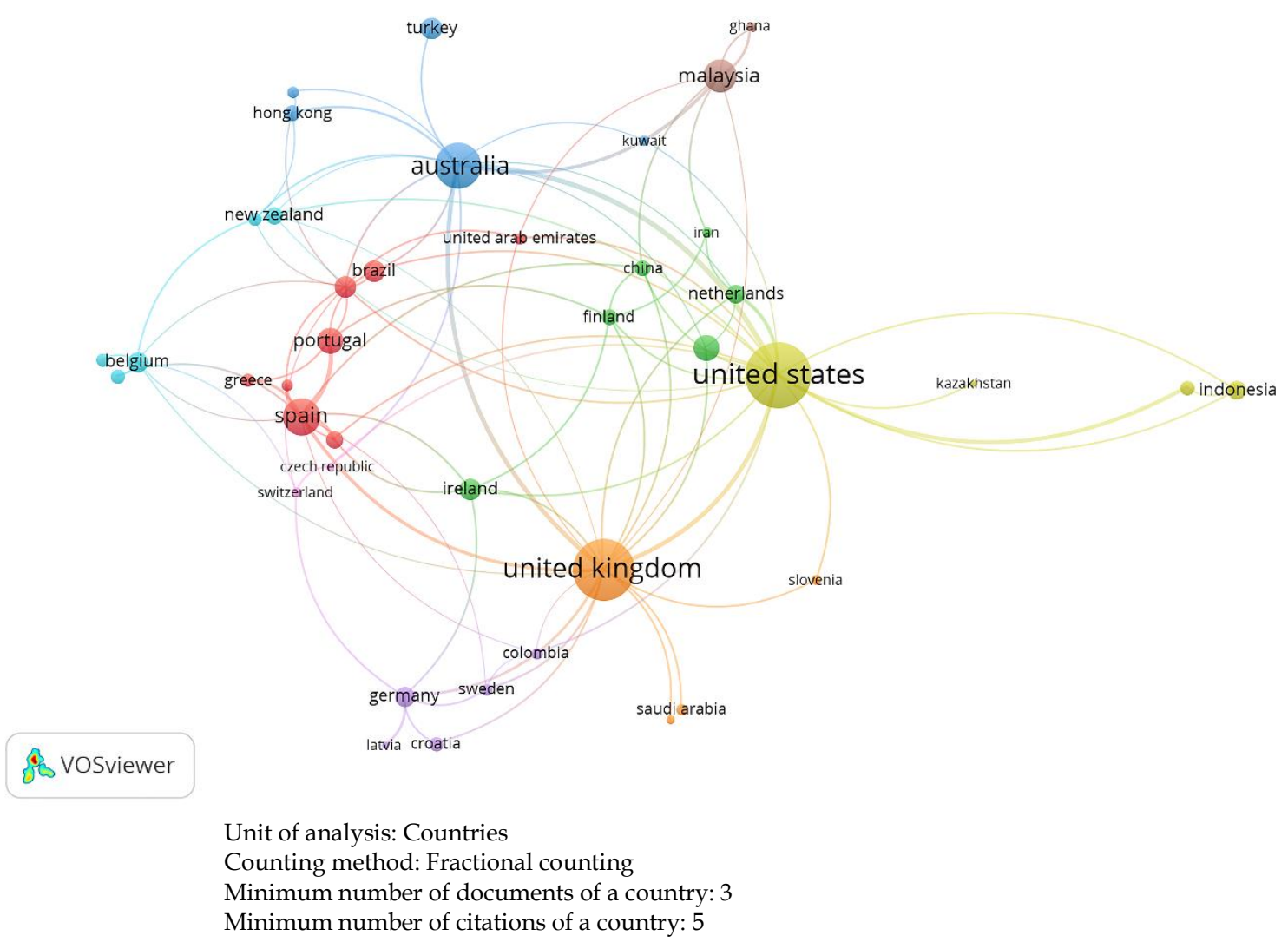

Figure 4. Network visualization map of the co-authorship by countries

A network visualization map of citations by country, with a minimum of five documents and ten citations per country, is shown in Figure 12. According to the circles, clusters, labels, and links, the United States produced the highest number of citations, followed by the United Kingdom, Australia, Spain, Malaysia, and Portugal, in that order. 


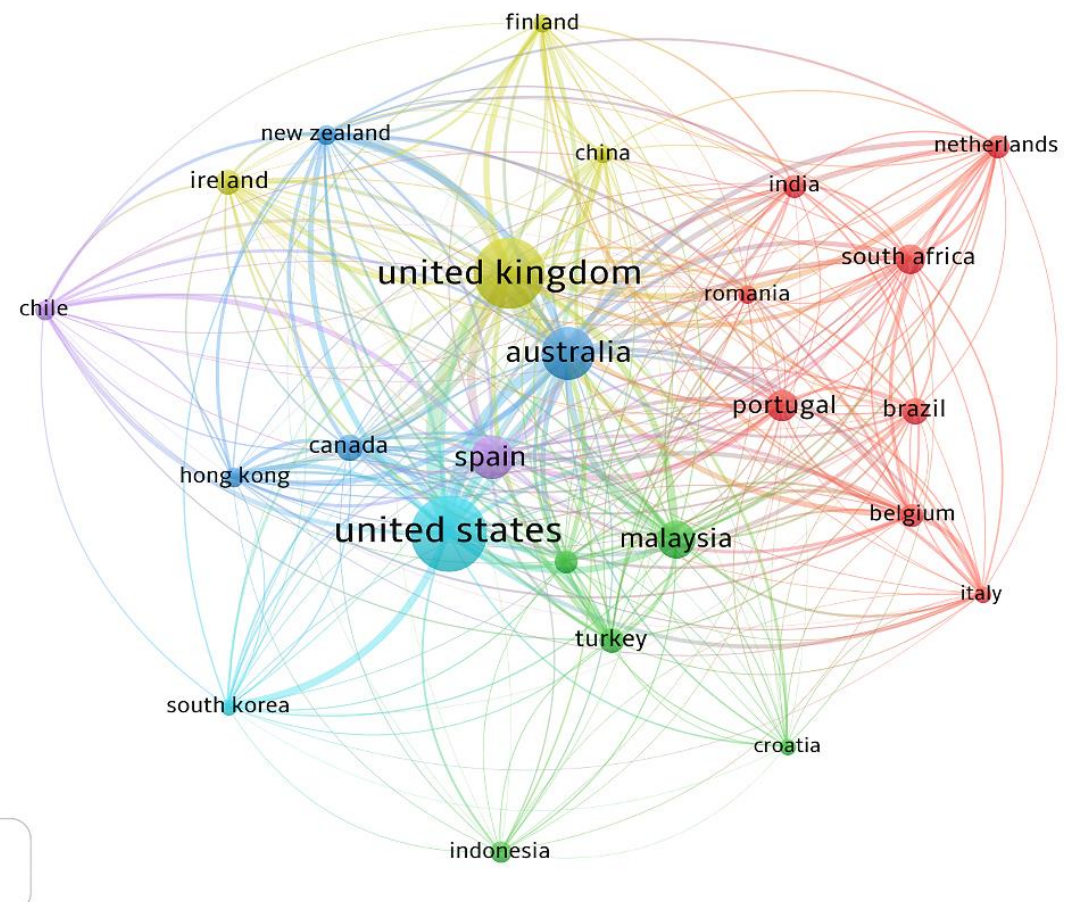

Minimum number of documents per country: 5

Minimum number of citations per country: 10

Figure 5 . Network visualization map of the citation by countries

\subsection{Number of authors per document}

The number of authors who contributed to a document was calculated by descriptive analysis, that is frequency and percentage, as shown in Table 9. Most of the publications had two authors (28.57\%), followed by three authors and one author $(25.75 \%)$ per document. Publications that had been prepared by five or more authors made up $8.36 \%$ of the total number of publications.

Table 10. Number of the author(s) per document

\begin{tabular}{|c|c|c|}
\hline Author count & Frequency & $\mathbf{\%} \mathbf{( N = 1 , 0 6 4 )}$ \\
\hline $0^{*}$ & 5 & 0.47 \\
\hline 1 & 274 & 25.75 \\
\hline 2 & 304 & 28.57 \\
\hline 3 & 278 & 26.12 \\
\hline 4 & 114 & 10.71 \\
\hline 5 & 53 & 4.98 \\
\hline 6 & 25 & 2.35 \\
\hline 7 & 5 & 0.47 \\
\hline 8 & 2 & 0.19 \\
\hline 9 & 2 & 0.19 \\
\hline 10 & 1 & 0.09 \\
\hline 11 & 1 & 0.09 \\
\hline (blank) & & 0.00 \\
\hline
\end{tabular}

${ }^{*}$ Conference review documents. No authors listed. 


\subsection{Most active authors}

This study also investigated the most active authors who published documents on BL. Table 11 lists 20 of the most active authors who had published at least six publications. The authors Kinchin, Hosein, Medland, Lygo-Baker, Warburton, Gash, Rees, Loughlin, Woods, Price, Usherwood had published the largest number of documents - in total 11 articles (2.08\%).

Table11. Most active authors

\begin{tabular}{|c|c|c|}
\hline Author names & \begin{tabular}{c|} 
No. of \\
publications
\end{tabular} & $\begin{array}{l}\text { Percentage } \\
(\%)\end{array}$ \\
\hline $\begin{array}{l}\text { Kinchin, I., Hosein, A., Medland, E., Lygo-Baker, S., Warburton, S., } \\
\text { Gash, D., Rees, R., Loughlin, C., Woods, R., Price, S. \& Usherwood, S }\end{array}$ & 11 & 2.08 \\
\hline $\begin{array}{l}\text { Bokolo A. Jr, Kamaludin, A., Romli, A., Farihan, A., Raffei, M., } \\
\text { Nincarean, D. A/L Eh Phon, Abdullah, A., Ming, G. L., Shuker, N. A., } \\
\text { Shukri Nordin, M., \& Baba, S. }\end{array}$ & 10 & 1.89 \\
\hline $\begin{array}{l}\text { Van der Heijden, K. B., Vermeulen, M. C., Donjacour, C. E., Gordijn, } \\
\text { M. C., Hamburger, H. L., Meijer, A. M., van Rijn, J.J., Vlak, M., \& } \\
\text { Weysen, T. }\end{array}$ & 9 & 1.70 \\
\hline $\begin{array}{l}\text { Sicilia, M-A., Lytras, M. D., Sánchez-Alonso, S., García-Barriocanal, E., } \\
\text { \& Zapata-Ros, M. }\end{array}$ & 9 & 1.70 \\
\hline $\begin{array}{l}\text { Schmid, R. F., Bernard, R. M., Borokhovski, E., Tamim, R., Abrami, P. } \\
\text { C., Wade, C. A., Surkes, M. A., \& Lowerison, G. }\end{array}$ & 8 & 1.51 \\
\hline $\begin{array}{l}\text { Nye, A., Hughes-Warrington, M., Roe, J., Russell, P., Peel, M., Deacon, } \\
\text { D., Laugesen, A., \& Kiem, P. }\end{array}$ & 8 & 1.51 \\
\hline $\begin{array}{l}\text { Vicente, H., Figueiredo, M., Dias, A., Marques, J., Araújo, Is., Maia, N., } \\
\text { Ribeiro, J., \& Neves, J. }\end{array}$ & 8 & 1.51 \\
\hline $\begin{array}{l}\text { Roberts, R., Wilson, A., Coveney, J., Lind, C., Tieman, J., George, S., } \\
\text { Gill, R., \& Tonkin, E. }\end{array}$ & 8 & 1.51 \\
\hline $\begin{array}{l}\text { Samah, N. A., Yaacob, A., Hussain, R. M. R., Yusoff, N. M., Meng, N. } \\
\text { Y., Othman, R., \& Hin, L. C. }\end{array}$ & 8 & 1.51 \\
\hline $\begin{array}{l}\text { Spronken-Smith, R., Bond, C., McLean, A., Frielick, S., Smith, N., } \\
\text { Jenkins, M., \& Marshall, S. }\end{array}$ & 7 & 1.32 \\
\hline $\begin{array}{l}\text { Araújo, L. S., Wasley, D., Perkins, R., Atkins, L., Redding, E., } \\
\text { Ginsborg, J., \& Williamon, A. }\end{array}$ & 7 & 1.32 \\
\hline $\begin{array}{l}\text { Maimunah, L., Marzulina, L., Herizal, H., Holandyah, M., Mukminin, } \\
\text { A., Pratama, R., \& Habibi, A. }\end{array}$ & 7 & 1.32 \\
\hline $\begin{array}{l}\text { Morelock, J. R., Lester, M. M., Klopfer, M. D., Jardon, A. M., Mullins, } \\
\text { R. D., Nicholas, E. L., \& Alfaydi, A. S. }\end{array}$ & 7 & 1.32 \\
\hline 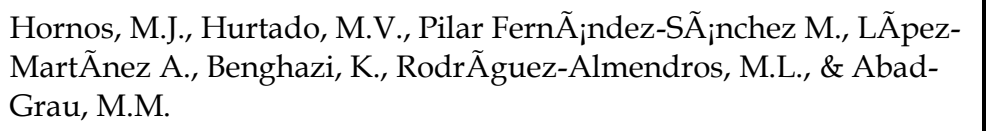 & 7 & 1.32 \\
\hline $\begin{array}{l}\text { Gregory, S., Scutter, S., Jacka, L., McDonald, M., Farley, H., \& } \\
\text { Newman, C. }\end{array}$ & 6 & 1.13 \\
\hline $\begin{array}{l}\text { Fong, R. W-T., Lee, J. C-K., Chang, C-Y., Zhang, Z., Ngai, A. C-Y., \& } \\
\text { Lim, C. P. }\end{array}$ & 6 & 1.13 \\
\hline Crust, L., Earle, K., Perry, J., Earle, F., Clough, A., \& Cloug & 6 & 1.13 \\
\hline
\end{tabular}




\begin{tabular}{|l|c|c|} 
Basit, T. N., Eardley, A., Borup, R., Shah, H., Slack, K., \& Hughes, A. & 6 & 1.13 \\
\hline $\begin{array}{l}\text { Kabassi, K., Dragonas, I., Ntouzevits, A., Pomonis, T., } \\
\text { Papastathopoulos, G., \& Vozaitis, Y. }\end{array}$ & 6 & 1.13 \\
\hline $\begin{array}{l}\text { Venturini, J. C., Pereira, B. A. D., Morales, R., Fleck, C. F., Batistella } \\
\text { Junior, Z., \& Nagel, M. D. B. }\end{array}$ & 6 & 1.13 \\
\hline $\begin{array}{l}\text { Dismore, H., McDermott, A., Witt, N., Stillwell, R., Neville, S., \& } \\
\text { Stone, M. }\end{array}$ & 6 & 1.13 \\
\hline
\end{tabular}

\subsection{Co-authorship by Authors}

The network visualization map of co-authorship is shown in Figure 6. Four clusters of authors, which are represented by four different colors, can be seen; they are linked by lines showing co-authorship within clusters and between clusters. There is inter-cluster authorship by Donche, V. and intra-cluster coauthorship with Stes, A.

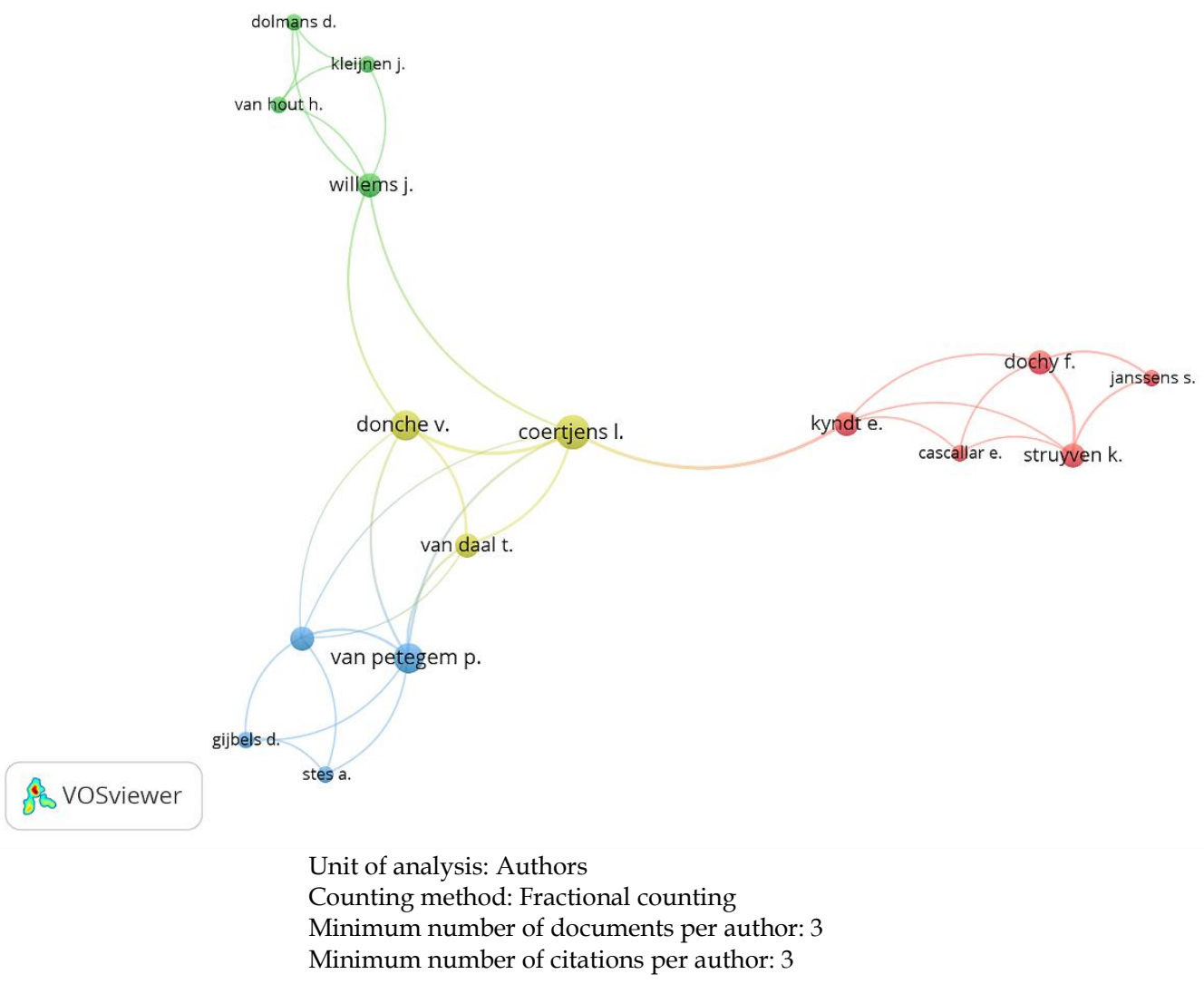

Figure 6. Network visualization map of co-authorship by authors

\subsection{Citation analysis}

Citation analysis is a conventional method administered in bibliometrics as a way to measure scientific characteristics, especially the number of researchers per publication, the rankings of universities and institutions (Waltman et al., 2012; Weingart, 2005), or publication impact (Frandsen \& Rousseau, 2004). Citation 
analysis can deliver evidence of interactions between diverse groups of academics, and provide a summary of the literature (Barth et al., 2014).

Citation metrics for documents retrieved on 11 December 2019 are shown in Table 13. As depicted, 1,064 papers were published in the 19 years from year 2000 to 2019 , with a total of 11,931 citations and an average of 627.95 citations annually. From the analysis, it can be concluded that papers were cited on average 11.21 times, and citations per author averaged around 4,127.37.

Table 12. Citation metrics

\begin{tabular}{|l|l|}
\hline \multicolumn{1}{|c|}{ Metrics } & \multicolumn{1}{c|}{ Data } \\
\hline Publication years & $2000-2019$ \\
\hline Citation years & $\mathrm{N}=19(2000-2019)$ \\
\hline Total papers & 1,064 \\
\hline Total citations & 11,931 \\
\hline Average citations per year & 627.95 \\
\hline Citations/paper & 11.21 \\
\hline Citations/author & $4,127.37$ \\
\hline Authors/paper & 2.53 \\
\hline Hirsch h-index & 45 \\
\hline Egghe g-index & 92 \\
\hline
\end{tabular}

\subsubsection{Citation analysis by documents}

Table 14 reveals the 20 most highly cited articles through Google Scholar (20002019) using the keywords, "blended learning", "perception", "engagement", "achievement", and "higher education". The authors, titles of the documents, years published, Google Scholar Cites, Google Scholar cites per year, Google Scholar cites per author, and Google Scholar rankings are also given in Table 14. "Blended Learning: Uncovering its Transformative Potential in Higher Education", by Garrison and Kanuka (2004), achieved the highest number of Google Scholar cites in 2014 (3,801) and highest Google Scholar rank, followed by "NMC Horizon Report: 2016 Higher Education Edition", by Johnson et al. (2016) $(3,129$ cites), and "From the Achievement Gap to the Education Debt: Understanding Achievement in US Schools", by Ladson-Billings (2006) $(2,819$ cites). Garrison and Vaughan (2008) (2,715 cites), who authored "Blended Learning in Higher Education: Framework, Principles, and Guidelines", held the third-place GS rank.

Table 13. Highly cited articles through Google Scholar (2000-2019)

\begin{tabular}{|c|c|c|c|c|c|}
\hline No. & Articles & $\begin{array}{c}\text { GS } \\
\text { Cites }\end{array}$ & \begin{tabular}{|c|} 
Average \\
GS \\
Cites/ \\
Year \\
\end{tabular} & $\begin{array}{l}\text { GS } \\
\text { Cites/ } \\
\text { Author }\end{array}$ & $\begin{array}{c}\text { GS } \\
\text { Rank }\end{array}$ \\
\hline 1 & $\begin{array}{l}\text { Garrison, D., \& Kanuka, H. (2004). Blended learning: Uncovering its } \\
\text { transformative potential in higher education. The Internet and Higher Education, } \\
7(2), 95-105 . \text { https:// doi.org/10.1016/j.iheduc.2004.02.001 }\end{array}$ & 3,801 & 253.4 & 1,901 & 1 \\
\hline 2 & $\begin{array}{l}\text { Tohnson L., Becker S., Cummins M., Estrada V., Freeman A., \& Hall C., (2016). } \\
\text { The New Media Consortium. United States. NMC horizon report: } 2016 \text { higher } \\
\text { education edition: 1-50. Sciepub.com. (2021). } \\
\text { http://www.sciepub.com/reference/303571. }\end{array}$ & 3,129 & 1,043 & 626 & 63 \\
\hline
\end{tabular}


3 Ladson-Billings, G. (2006). From the achievement gap to the education debt: Understanding achievement in U.S. Schools. Educational Researcher, 35(7), 3-12. https://doi.org/10.3102/0013189x035007003

4 Garrison, D. R., \& Vaughan, N. D. (2008). Blended learning in higher education: Framework, principles, and guidelines. John Wiley \& Sons. http:/ / dx.doi.org/10.1002/9781118269558

5 Graham, C.R. (2006). Blended learning systems definition, current trends, and future directions. In Bonk, C.J. and Graham, C.R., Eds., Handbook of blended learning. Global Perspectives, Local Designs, Pfeiffer Publishing, San Francisco, 3-21. References - Scientific Research Publishing. Scirp.org. (2021). https:// www.scirp.org/(S(i43dyn45teexjx455qlt3d2q))/reference/ReferencesPa pers.aspx?ReferenceID=2143722.

6 Gurin, P., Dey, E., Hurtado, S., \& Gurin, G. (2002). Diversity and higher education: Theory and impact on educational outcomes. Harvard Educational Review, 72(3), 330-367. https:/ / doi.org/10.17763/haer.72.3.01151786u134n051

7 Davis-Kean, P. (2005). The influence of parent education and family income on child achievement: The indirect role of parental expectations and the home environment. Journal of Family Psychology, 19(2), 294-304. https:// doi.org/10.1037/0893-3200.19.2.294

8 Brubacher, J. S., \& Rudy, W. (1997). Higher education in transition: A history of American colleges and universities. Transaction Publishers. https://doi.org/10.4324/9780203790076

9 Kuh, G., Cruce, T., Shoup, R., Kinzie, J., \& Gonyea, R. (2008). Unmasking the effects of student engagement on first-year college grades and persistence. The Journal of Higher Education, 79(5), 540-563. https://doi.org/10.1353/ihe.0.0019

10 Altbach, P., Reisberg, L., \& Rumbley, L. (2010). Tracking a global academic revolution. Change: The Magazine of Higher Learning, 42(2), 30-39. https:// doi.org/10.1080/00091381003590845

11 Kuh, G. (2003). What we're learning about student engagement from NSSE: Benchmarks for effective educational practices. Change: The Magazine of Higher Learning, 35(2), 24-32. https:/ / doi.org/10.1080/00091380309604090

12 Carini, R., Kuh, G., \& Klein, S. (2006). Student engagement and student learning: Testing the linkages. Research in Higher Education, 47(1), 1-32. https://doi.org/10.1007/s11162-005-8150-9

13 Kuh, G. (2001). Assessing what really matters to student learning inside the National Survey of Student Engagement. Change: The Magazine of Higher Learning, 33(3), 10-17. https:/ / doi.org/10.1080/00091380109601795

14 Goldhaber, D., \& Brewer, D. (2000). Does teacher certification matter? High school teacher certification status and student achievement. Educational Evaluation and Policy Analysis, 22(2), 129-145. https://doi.org/10.3102/01623737022002129

15 Zhao, C., \& Kuh, G. (2004). Adding value: Learning communities and student engagement. Research in Higher Education, 45(2), 115-138. https:/ / doi.org/10.1023/b:rihe.0000015692.88534.de

16 Lee, J., \& Bowen, N. (2006). Parent involvement, cultural capital, and the achievement gap among elementary school children. American Educational Research Journal, 43(2), 193-218. https:/ / doi.org/10.3102/00028312043002193

17 Galston, W. (2001). Political knowledge, political engagement, and civic education. Annual Review of Political Science, 4(1), 217-234. https:/ / doi.org/10.1146/annurev.polisci.4.1.217

18 Smith, K., Sheppard, S., Johnson, D., \& Johnson, R. (2005). Pedagogies of engagement: Classroom-based practices. Journal of Engineering Education, 94(1), 87-101. https:// doi.org/10.1002/j.2168-9830.2005.tb00831.x

19 Osguthorpe, R. T., \& Graham, C. R. (2003). Blended learning environments: Definitions and directions. Quarterly Review of Distance Education, 4(3), 227-33. https:/ / eric.ed.gov/?id=EJ678078

20 Braxton, J. M., Hirschy, A. S., \& McClendon, S. A. (2011). Understanding and reducing college student departure. ASHE-ERIC higher education report. Volume 30, No 3. Jossey-Bass. https://eric.ed.gov/?id=ED501184

${ }^{*}$ GS - Google Scholar; NSSE - National Survey of Student Engagement

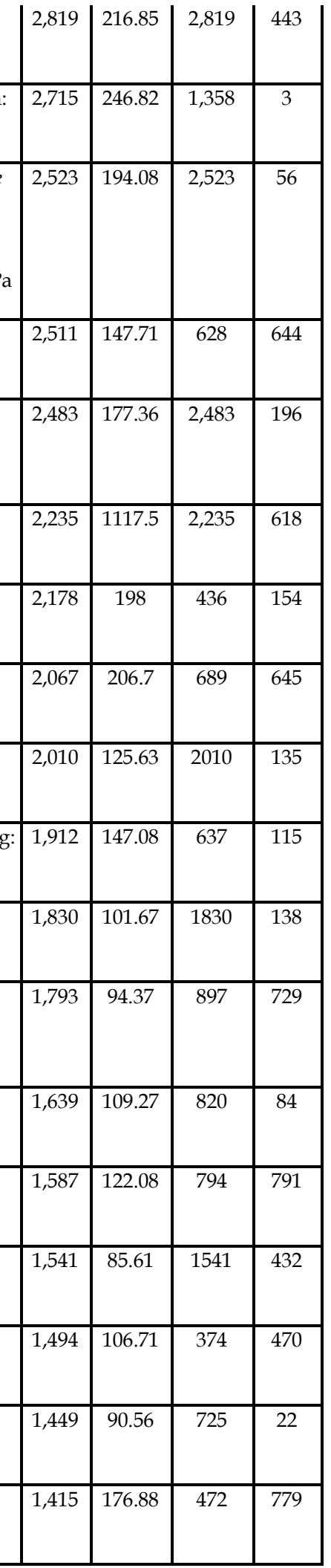

Citation by documents was analyzed using VOSviewer, with a minimum number of five citations per document as cutoff. Garrison and Kanuka (2004) garnered the 
most citations, followed by Roblyer (2010), Tomlinson (2008), Busato (2000), and Struyven (2005).

VOSviewer

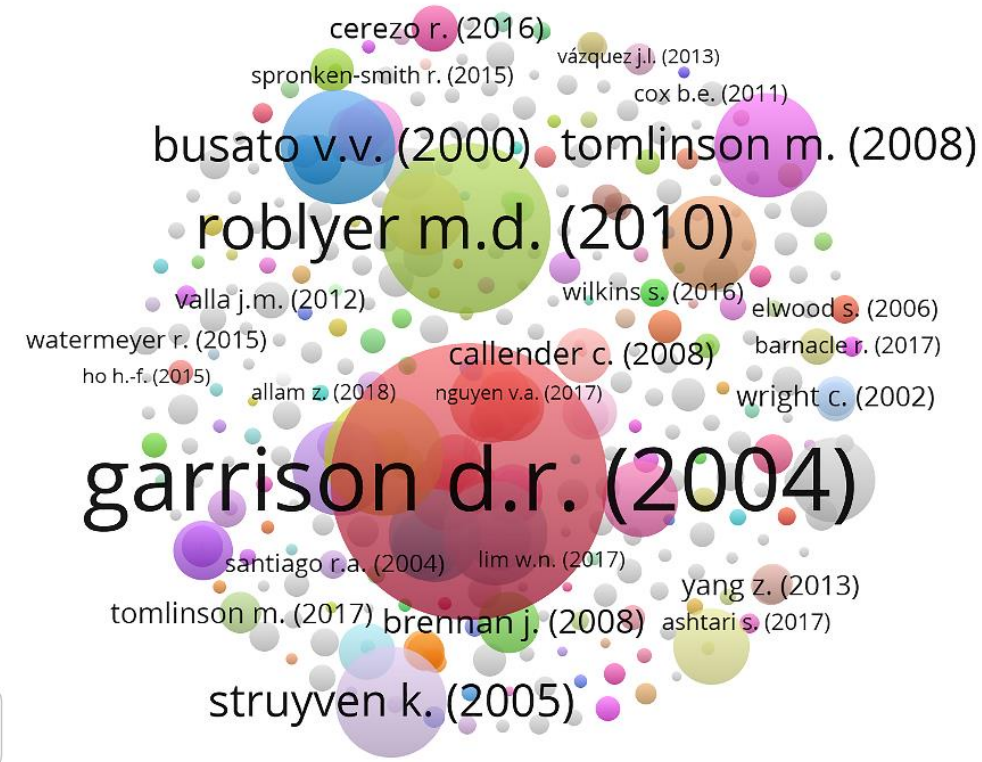

Minimum number of citations of a document: 5

Figure 7: Network visualization map of the citations by document

Table 14. Summary of findings

\begin{tabular}{|c|c|c|}
\hline No. & Analysis & Finding \\
\hline 1 & Most common document type & Article \\
\hline 2 & Most common source type & Journal \\
\hline 3 & Year with greatest number of publications & 2018 \\
\hline 4 & Most widely used language & English \\
\hline 5 & Most common subject area & The social sciences \\
\hline 6 & Most active journal & Studies in Higher Education \\
\hline 7 & Most influential institution & Monash University \\
\hline 8 & Keyword most frequently used* & Higher education \\
\hline 9 & Country producing the most publications & United States \\
\hline 10 & Authors per document (Most) & Two authors \\
\hline 11 & Most active author(s) & $\begin{array}{l}\text { Kinchin, I., Hosein, A., Medland, } \\
\text { E., Lygo-Baker, S., Warburton, } \\
\text { Gash, D., Rees, R., Loughlin, C., } \\
\text { Woods, R., Price, S., Usherwood, } \\
\text { S. }\end{array}$ \\
\hline 12 & Co-authorship by authors & $\begin{array}{l}\text { Donche, V., De Maeyer, S., } \\
\text { Coertjens, L., van Daal, T., \& van } \\
\text { Petegem, P. }\end{array}$ \\
\hline 13 & Hirsch h-index/Egghe g-index & $45 / 92$ \\
\hline 14 & Highest GS cites and GS rank & Garrison \& Kanuka (2016) \\
\hline
\end{tabular}




\section{Discussion}

Document type and source type were used as indicators in this bibliometric analysis of publications in a particular period, as suggested by Sigogneau (2000). It is clear from the findings that most of the document types in this study were articles, which is similar to findings by Yang et al. (2017) and Halverson (2012), followed by conference papers and book chapters. Journals made up the highest percentage of source types, followed by books and conference proceedings.

Research productivity analysis found that publications have proliferated rapidly and attracted greater research interest, especially between 2016 and 2018. This is confirmed by Güzer and Caner (2014) and Cheng et al. (2014), who cite similar trends in their research findings. This finding is important for further research into ways educators and administrators could organize learning environments to support effective learning using BL. In addition, the results of this study show that the English language, as the international language for scientific publication, is the most frequently used language in the Scopus database over the timespan of this study (Ferguson et al., 2011; Sweileh et al., 2017).

As BL is a field in the social sciences, it is not surprising that more than half of all publications are from this subject area. However, there is still a shortage of quantitative studies in BL. Therefore, the results of this research represents a step forward, towards developing empirical studies (Gemin \& Pape, 2017; Heafner \& Handler, 2018; Stevens et al., 2018; Raman \& Rathakrishnan, 2019). In addition, evidence from this study suggests that the most active journal at the forefront of BL thematic analysis is Studies in Higher Education, ${ }^{1}$ a prominent, global, journalpublishing, research-based journal.

Author keyword analysis and network visualization of co-occurrences suggest that the most widely used keywords were higher education and blended learning. However, few research studies mention perception, engagement, and achievement. Further investigations are required to analyze BL trends concerning student achievement, perception, and engagement. The United States was the country that contributed the greatest number of publications, which is confirmed by the study of Yang et al. (2017). In addition, Monash University, Australia, was the institution associated with the greatest number of documents published on blended learning. The findings of this research support research by Halverson et al. (2012), who found that Garrison and Manuka are authors with the most Google Scholar citations.

Results of a bibliometric analysis may vary according to the database used (e.g., Web of Science or Google Scholar), and the inclusion of other search terms (e.g., e-learning). Some highly cited articles on topics related to BL were published in certain journals (e.g., PLoS ONE, PNAS) that did not contain the particular keywords of this study. Thus, to demonstrate the keywords network, this study analyzed only documents with obtainable author keywords. Furthermore, a citation threshold of fewer than 200 citations was chosen to determine highly cited articles which were published between 2000 and the end of 2019, with the majority

${ }^{1}$ https://www.tandfonline.com/loi/cshe20 
being published between 2006 and 2018. Thus, all analysis, discussions, and conclusions offered in this study were interpreted within the framework of these limitations.

Although Scopus comprises a large number of journals, it is limited to recent articles, and articles of lesser impact (Chadegani et al., 2013); therefore, exploration of other scientific databases, such as Web of Science, is recommended to access more peer-reviewed articles, which could be investigated to increase the scalability of the approach further. Other search keyword combinations should be tried, in order to obtain a wider range of publications and up-to-date citations of BL in higher education. It is also recommended that bibliometric analysis is carried out together with systematic literature reviews, for more in-depth research on existing literature. A further recommendation is to use visualization tools such as HistCite.

\section{Conclusion}

BL in higher education is an undoubtedly emerging and increasingly exploited method of instruction in the new millennium. This analysis contributes to the body of knowledge by presenting the results of an investigation into scholarly networks and worldwide research trends on BE in higher education, more precisely, on the aspects of perception, achievement, and engagement from 2000 to 2019. In referring to 1,064 highly cited research articles retrieved from the Scopus database, this investigation gathered bibliometric information related to publication outputs, journals, author keywords, countries, institutions, and authors. The investigation into the visibility of work on BL published in highly cited journals in the past two decades reveals that BL has gained significant attention among educators and researchers. The findings of this bibliometric analysis can become the basis of and a pivotal platform for spurring further research in $\mathrm{BL}$, and can promote its significant prevalence in the higher education context, both locally and globally. This is the first wide-ranging study about BL, perception, achievement, and engagement in higher education. It can serve as a starting point for further analysis of other variables that affect the BL approach.

\section{References}

Ahmi, A., \& Mohamad, R. (2019). Bibliometric analysis of global scientific literature on web accessibility. International Journal of Recent Technology and Engineering, 7(6), 250-258. http:// www.ijstr.org/ paper-references.php?ref=IJSTR-0819-21689

Alamri, M. (2021). Using blended project-based learning for students' behavioral intention to use and academic achievement in higher education. Education Sciences, 11(5), 207. https:// doi.org/10.3390/educsci11050207

Aria, M., \& Cuccurullo, C. (2017). Bibliometrix: An r-tool for comprehensive science mapping analysis. Journal of Informetrics, 11(4), 959-975. https://doi.org/10.1016/j.joi.2017.08.007

Barth, M., Haustein, S., \& Scheidt, B. (2014). The life sciences in German-Chinese cooperation: An institutional-level co-publication analysis. Scientometrics, 98(1), 99-117. https:// doi.org/10.1007/s11192-013-1147-9

Börner, K., Chen, C., \& Boyack, K. (2003). Visualising knowledge domains. Annual Review of Information Science And Technology, 37(1), 179-255. https://doi.org/10.1002/aris.1440370106 
Busato, V., Prins, F., Elshout, J., \& Hamaker, C. (2000). Intellectual ability, learning style, personality, achievement motivation and academic success of psychology students in higher education. Personality and Individual Differences, 29(6), 1057 1068. https:/ / doi.org/10.1016/s0191-8869(99)00253-6

Chadegani, A., Salehi, H., Yunus, M., Farhadi, H., Fooladi, M., Farhadi, M., \& Ebrahim, N. (2013). A comparison between two main academic literature collections: Web of Science and Scopus Databases. Asian Social Science, 9(5), 18-26. https://doi.org/10.5539/ass.v9n5p18

Chen, C. (2003). Mapping scientific frontiers. Springer. https://www.springer.com/gp/book/9781447151272

Cheng, B., Wang, M., Mørch, A. I., Chen, N.-S., Kinshuk, \& Spector, J. M. (2014). Research on e-learning in the workplace 2000-2012: A bibliometric analysis of literature. Educational Research Review, 11, 56-72. https://doi.org/10.1016/j.edurev.2014.01.001

Cooney, M., Gupton, P., \& O'Laughlin, M. (2000). Blurring the lines of play and work to create blended classroom learning experiences. Early Childhood Education Journal, 27(3), 165-171. https:/ / doi.org/10.1007/bf02694230

Diem, A., \& Wolter, S. C. (2013). The use of bibliometrics to measure research performance in education sciences. Research in Higher Education, 54(1), 86-114. https://doi.org/10.1007/s11162-012-9264-5

Ding, J., Ahlgren, P., Yang, L., \& Yue, T. (2016). Document type profiles in Nature, Science, and PNAS: Journal and country level. Journal of Data and Information Science, 1(3), 27-41. https://doi.org/10.20309/jdis.201618

Donche, V., De Maeyer, S., Coertjens, L., van Daal, T., \& van Petegem, P. (2013). Differential use of learning strategies in first-year higher education: The impact of personality, academic motivation, and teaching strategies. British Journal of Educational Psychology, 83(2), 238-251. https:/ / doi.org/10.1111/bjep.12016

Dwivedi, A., Dwivedi, P., Bobek, S., \& Sternad Zabukovšek, S. (2019). Factors affecting students' engagement with online content in blended learning. Kybernetes, 48(7), 1500-1515. https://doi.org/10.1108/k-10-2018-0559

Ellegaard, O., \& Wallin, J. A. (2015). The bibliometric analysis of scholarly production: How great is the impact? Scientometrics, 105, 1809-1831. https:/ / doi.org/10.1007/s11192-015-1645-z

Ferguson, G., Pérez-Llantada, C., \& Plo, R. (2011). English as an international language of scientific publication: A study of attitudes. World Englishes, 30(1), 41-59. https://doi.org/10.1111/j.1467-971x.2010.01656.x

Fox, M. (1983). Publication productivity among scientists: A critical review. Social Studies of Science, 13(2), 285-305. https:/ / doi.org/10.1177/030631283013002005

Frandsen, T., \& Rousseau, R. (2004). Article impact calculated over arbitrary periods. Journal of The American Society for Information Science and Technology, 56(1), 58-62. https://doi.org/10.1002/asi.20100

Garrison, D., \& Kanuka, H. (2004). Blended learning: Uncovering its transformative potential in higher education. The Internet and Higher Education, 7(2), 95-105. https:// doi.org/10.1016/j.iheduc.2004.02.001

Garrison, D. R., \& Vaughan, N. D. (2008). Blended learning in higher education: Framework, principles, and guidelines. John Wiley \& Sons. http:/ / dx.doi.org/10.1002/9781118269558

Gemin, B. \& Pape, L. (2017). Keeping pace with K-12 online learning, 2016 [Report]. Evergreen Education Group. https://www.evergreenedgroup.com/keeping-pace-reports/ 
Graham, C. R. (2018). Current research in blended learning. In Moore, M. G., \& Diehl, W. C. (Eds.), Handbook of Distance Education (pp. 173-188). Routledge. https://doi.org/10.4324/9781315296135-15

Güzer, B., \& Caner, H. (2014). The past, present and future of blended learning: An in depth analysis of literature. Procedia - Social And Behavioral Sciences, 116, 45964603. https://doi.org/10.1016/j.sbspro.2014.01.992

Halverson, L., Graham, C., Spring, K., \& Drysdale, J. (2012). An analysis of high impact scholarship and publication trends in blended learning. Distance Education, 33(3), 381-413. https://doi.org/10.1080/01587919.2012.723166

Harzing, A. W. (2020). Publish or Perish. https://harzing.com/blog/2020/02/66thedition-of-the-journal-quality-list-on-line

Hattie, J., \& Anderman, E. M. (Eds.). (2013). International guide to student achievement. Routledge. https://doi.org/10.4324/9780203850398

Heafner, T. L., \& Handler, L. K. (2018). Online, hybrid, blended, and technology-mediated learning in social studies. In R. Ferdig \& K. Kennedy (Eds.), Handbook of research on K-12 online and blended learning (pp. 335-357). ETC Press. https://www.academia.edu/37013644/Handbook_of_Research_on_K12_and_B lending_Learning_Second_Editio.pdf

Hsiao, C., Tang, K., \& Liu, J. (2015). Citation-based analysis of literature: a case study of technology acceptance research. Scientometrics, 105(2), 1091-1110. https://doi.org/10.1007/s11192-015-1749-5

Johnson L., Becker S., Cummins M., Estrada V., Freeman A., \& Hall C., (2016). The New Media Consortium. United States. NMC horizon report: 2016 higher education edition: 1-50. Sciepub.com. (2021). http://www.sciepub.com/reference/303571.

Klavans, R., \& Boyack, K. (2006). Quantitative evaluation of large maps of science. Scientometrics, 68(3), 475-499. https://doi.org/10.1007/s11192-006-0125-x

Kinchin, I., Hosein, A., Medland, E., Lygo-Baker, S., Warburton, S., Gash, D., Rees, R., Loughlin, C., Woods, R., Price, S., \& Usherwood, S. (2015). Mapping the development of a new MA programme in higher education: comparing privately held perceptions of a public endeavour. Journal of Further and Higher Education, 41(2), 155-171. https:// doi.org/10.1080/0309877x.2015.1070398

Krause, K. L., \& Coates, H. (2008). Students' engagement in first-year university. Assessment \& Evaluation in Higher Education, 33(5), 493-505. https:// doi.org/10.1080/02602930701698892

Kuh, G. D. (2009). The national survey of student engagement: Conceptual and empirical foundations. New Directions for Institutional Research, 2009(141), 5-20. https://doi.org/10.1002/ir.283

Ladson-Billings, G. (2006). From the Achievement Gap to the Education Debt: Understanding Achievement in U.S. Schools. Educational Researcher, 35(7), 3-12. https://doi.org/10.3102/0013189x035007003

Lane, S., Hoang, J., Leighton, J., \& Rissanen, A. (2021). Engagement and satisfaction: Mixed-method analysis of blended learning in the sciences. Canadian Journal of Science, Mathematics and Technology Education, 21(1), 100-122. https://doi.org/10.1007/s42330-021-00139-5

Lee, I-S., Lee, H., Chen, Y-H., \& Chae, Y. (2020). Bibliometric analysis of research assessing the use of acupuncture for pain treatment over the past 20 years. Journal of Pain Research, 13, 367-376. https://doi.org/10.2147/jpr.s235047

Lee, M. H., Wu, Y. T., \& Tsai, C. C. (2009). Research trends in science education from 2003 to 2007: A content analysis of publications in selected journals. International Journal of Science Education, 31(15), 1999-2020. https://doi.org/10.1080/09500690802314876 
Lewis, A. (2001). The issue of perception: Some educational implications. Educare, 30(1). https://hdl.handle.net/10520/EJC31721

Li, J., Burnham, J. F., Lemley, T., \& Britton, R. M. (2010). Citation analysis: Comparison of Web of Science ${ }^{\circledR}$, Scopus ${ }^{\mathrm{TM}}$, SciFinder ${ }^{\circledR}$, and Google Scholar. Journal of Electronic Resources in Medical Libraries, 7(3), 196-217. https:// doi.org/10.1080/15424065.2010.505518

Mansour, A., Ahmi, A., Popoola, O., \& Znaimat, A. (2021). Discovering the global landscape of fraud detection studies: a bibliometric review. Journal Of Financial Crime. Advance online publication. https://doi.org/10.1108/jfc-03-2021-0052

Michels, C., \& Fu, J-Y. (2014). Systematic analysis of coverage and usage of conference proceedings in web of science. Scientometrics, 100(2), 307-327. https://doi.org/10.1007/s11192-014-1309-4

Owston, R., York, D., \& Murtha, S. (2013). Student perceptions and achievement in a university blended learning strategic initiative. The Internet and Higher Education, 18, 38-46. https://doi.org/10.1016/j.iheduc.2012.12.003

Raman, A., \& Rathakrishnan, M. (2019). Blended learning in higher education 4.0. A brief review. In A. Raman, \& M Ratharishnan (Eds.), Redesigning higher education initiatives for industry 4.0 (pp. 70-84). IGI Global. https://doi.org/10.4018/978-15225-7832-1.ch005

Reynolds, P. D. (1971). A primer in theory construction. Bobbs-Merrill.

Roblyer, M. D., McDaniel, M., Webb, M., Herman, J., \& Witty, J. V. (2010). Findings on Facebook in higher education: A comparison of college faculty and student uses and perceptions of social networking sites. The Internet and Higher Education, 13(3), 134-140. https://doi.org/10.1016/j.iheduc.2010.03.002

Rusly, F. H., Ahmi, A., Yakimin, Y., Talib, A., \& Rosli, K. (2019). Global perspective on payroll system patent and research: A bibliometric performance. International Journal of Recent Technology and Engineering, 8(2S2), 148-157. https://doi.org/10.35940/ijrte.b1028.0782s219

Skupin, A. (2004). The world of geography: Visualising a knowledge domain with cartographic means. Proceedings of the National Academy of Sciences, 101(Suppl 1), 5274-5278. https://www.pnas.org/content/pnas/101/suppl_1/5274.full.pdf.

Sigogneau, A. (2000). An analysis of document types published in journals related to physics: Proceeding Papers Recorded in the Science Citation Index Database. Scientometrics, 47, 589-604. https://doi.org/10.1023/A:1005628218890

Stes, A., de Maeyer, S., Gijbels, D., \& van Petegem, P. (2013). Effects of teachers instructional development on students' study approaches in higher education. $\begin{array}{llll}\text { Studies in } \quad \text { Higher } & \text { Education, }\end{array}$ https:// doi.org/10.1080/03075079.2011.562976

Stevens, M., Borup, J., \& Barbour, M.K. (2018). Preparing social studies teachers and librarians for blended teaching, Contemporary Issues in Technology and Teacher Education 18(4). https://citejournal.org/volume-18/issue-4-18/socialstudies/preparing-social-studies-teachers-and-librarians-for-blended-teaching

Struyven, K., Dochy, F., \& Janssens, S. (2005). Students' perceptions about evaluation and assessment in higher education: a review. Assessment $\mathcal{E}$ Evaluation in Higher Education, 30(4), 325-341. https:/ / doi.org/10.1080/02602930500099102

Sweileh, W. M., Al-Jabi, S. W., AbuTaha, A. S., Zyoud, S. H., Anayah, F. M., \& Sawalha, A. F. (2017). Bibliometric analysis of worldwide scientific literature in mobilehealth: 2006-2016. BMC Medical Informatics and Decision Making, 17(1). https://doi.org/10.1186/s12911-017-0476-7

Tomlinson, B. (Ed.). (2008). English language learning materials: A critical review. Bloomsbury Publishing. https://doi.org/10.5040/9781474212182 
Tibaná-Herrera, G., Fernández-Bajón, M. T., \& De Moya-Anegón, F. (2018). Categorization of E-learning as an emerging discipline in the world publication system: a bibliometric study in SCOPUS. International Journal of Educational Technology in Higher Education, 15(1). https:// doi.org/10.1186/s41239-018-0103-4

Van Eck, N. J., \& Waltman, L. (2010). Software survey: VOSviewer, a computer program for bibliometric mapping. Scientometrics, 84(2), 523-538. https://doi.org/10.1007/s11192-009-0146-3

Van Eck, N. J., \& Waltman, L. (2020, April 1). VOSviewer manual. Manual for VOSviewer version 1 .6.15. Universiteit Leiden, 1(1). VOSviewer Manual. https://www.vosviewer.com/documentation/Manual_VOSviewer_1.6.15.pdf

Voci, E., \& Young, K. (2001). Blended learning working in a leadership development programme. Industrial and Commercial Training, 33(5), 157-161. https://doi.org/10.1108/00197850110398927

Waltman, L., Calero-Medina, C., Kosten, J., Noyons, E. C. M., Tijssen, R. J. W., van Eck, N. J., van Leeuwen, T. N., van Raan, A. F. J., Visser, M. S., \& Wouters, P. (2012). The Leiden ranking 2011/2012: Data collection, indicators, and interpretation. Journal of the American Society for Information Science and Technology, 63(12), 2419-2432. https:// doi.org/10.1002/asi.22708

Weingart, P. (2005). Impact of bibliometrics upon the science system: Inadvertent consequences? Scientometrics, 62(1), 117-131. https://doi.org/10.1007/s11192005-0007-7

Yang, L., Sun, T., \& Liu, Y. (2017). A bibliometric investigation of flipped classroom research during 2000-2015. International Journal of Emerging Technologies in Learning (IJET), 12(06), 178. https:// doi.org/10.3991/ijet.v12i06.7095

Zare, F., Elsawah, S., Iwanaga, T., Jakeman, A. J., \& Pierce, S. A. (2017). Integrated water assessment and modelling: A bibliometric analysis of trends in the water resource $\begin{array}{lllll}\text { sector. Journal of Hydrology, 552, } & \text { 765-778. }\end{array}$ http://doi.org/10.1016/j.jhydrol.2017.07.031

Zuccala, A., \& van Leeuwen, T. (2011). Book reviews in humanities research evaluations. Journal of the American Society for Information Science and Technology, 62(10), 19791991. https:// doi.org/10.1002/asi.21588 